\title{
高齢者，有病者を診察する際の顎口腔領域の 画像診断の重要性
}

\author{
飯久保正弘 ${ }^{1,2)}$ \\ Importance of diagnostic images of the oral \\ and maxillofacial regions for the elderly \\ or medically compromised patients
}

\author{
IIKUBO Masahiro $^{1,2)}$
}

\begin{abstract}
It has been revealed that the oral management, for example oral care and dental treatment, is one option for preventing postoperative complications such as pneumonia and has been increased that the number of referral patients with systemic diseases from the medical doctors before medical treatment. Therefore, the dentists need to be correctly diagnosed imaging about the presence or absence of a dental disease which is problematic for patient's systemic treatment. Depending on the systemic diseases, the diseases itself or medications may evoke the oral symptoms. The oral surgeons need sufficient knowledge about the image findings of these systemic diseases.
\end{abstract}

Key words: perioperative (周術期), systemic disease (全身疾患), diagnostic image (画像診断)

は じめに

有病者に対する手術前後の口腔ケアは, 誤嚥性肺炎や術 後感染症などの合併症の発生を減少させることができ, 近 年, 周術期口腔管理が重要視されている ${ }^{1,2)}$. 平成 24 年に 改訂された「がん対策推進基本計画」では,「各種がん治療 の副作用・合併症の予防や軽減など, 患者の更なる生活の 質の向上を目指し, 医科歯科連携による口腔ヶアの推進を はじめ, 食事療法などによる栄養管理やリハビリテーショ ンの推進など, 職種間連携を推進する」という一文が加え られた。現在の診療報酬では, がん治療, 心臓血管手術, 臓器移植術, 人工関節置換術等の整形外科手術などの前後 に，「周術期口腔機能管理」が算定できる。この診療報酬は， 歯科単独ではなく, 医科柬科連携にもとづく点数であり,

1) 東北大学大学院歯学研究科口腔診断学分野

(主任：高橋 哲教授)

2) 東北大学病院周術期口腔支援センター (主任：飯久保正弘センター長)

${ }^{1)}$ Division of Oral Diagnosis, Tohoku University Graduate School of Dentistry (Chief: Prof. TAKAHASHI Tetsu)

${ }^{2)}$ Tohoku University Hospital, Perioperative Oral Care Support Center (Chief: Dr. IIKUBO Masahiro)
疾患の治療ではなく合併症の予防を目的とする。このよう な, 従来の㐘科医療保険にはなかった, 新たな診療体系に より, 口腔に何ら自覚症状のない有病者が, 医科の治療 (手 術）を円滑に行う目的で㐘科を受診する機会が増加してい る。口腔外科医は, さまざまな全身疾患有病者の㐘科治療 を行うにあたって, 患者が受ける治療 (手術, 放射線療法, 化学療法など) と㐘科治療上の注意点を熟知し, 個々の患 者に適した㐘科治療を適切な時期に行う必要がある.

本稿では, 高齢者や有病者の口腔を診療する上で必要な 画像診断を中心に, 症例を交えて解説する.

\section{1. 加齢変化（骨粗鬆症と動脈硬化）}

加齢に伴い骨量は低下し, 骨粗鬆症のリスクが高まる. 骨粗鬆症患者は軽微な外力で椎体, 大腿骨, 橈骨などが骨 折しやすくなり，とくに大腿骨骨折では，寝たきりになるリ スクや骨折後の死亡率が上昇する ${ }^{3)}$ 。下顎骨は，下縁皮質 骨が加歯や閉経後にも歯による影響を受けにくく, 他の全 身骨の変化と類似している ${ }^{4)}$. そのため, パノラマX線写 真を用いた骨粗鬆症スクリーニングでは，下顎骨下縁を指 標とする ${ }^{5,6)}$. 皮質骨の「厚み」を指標とする場合は図 $\mathbf{1 A}$ 

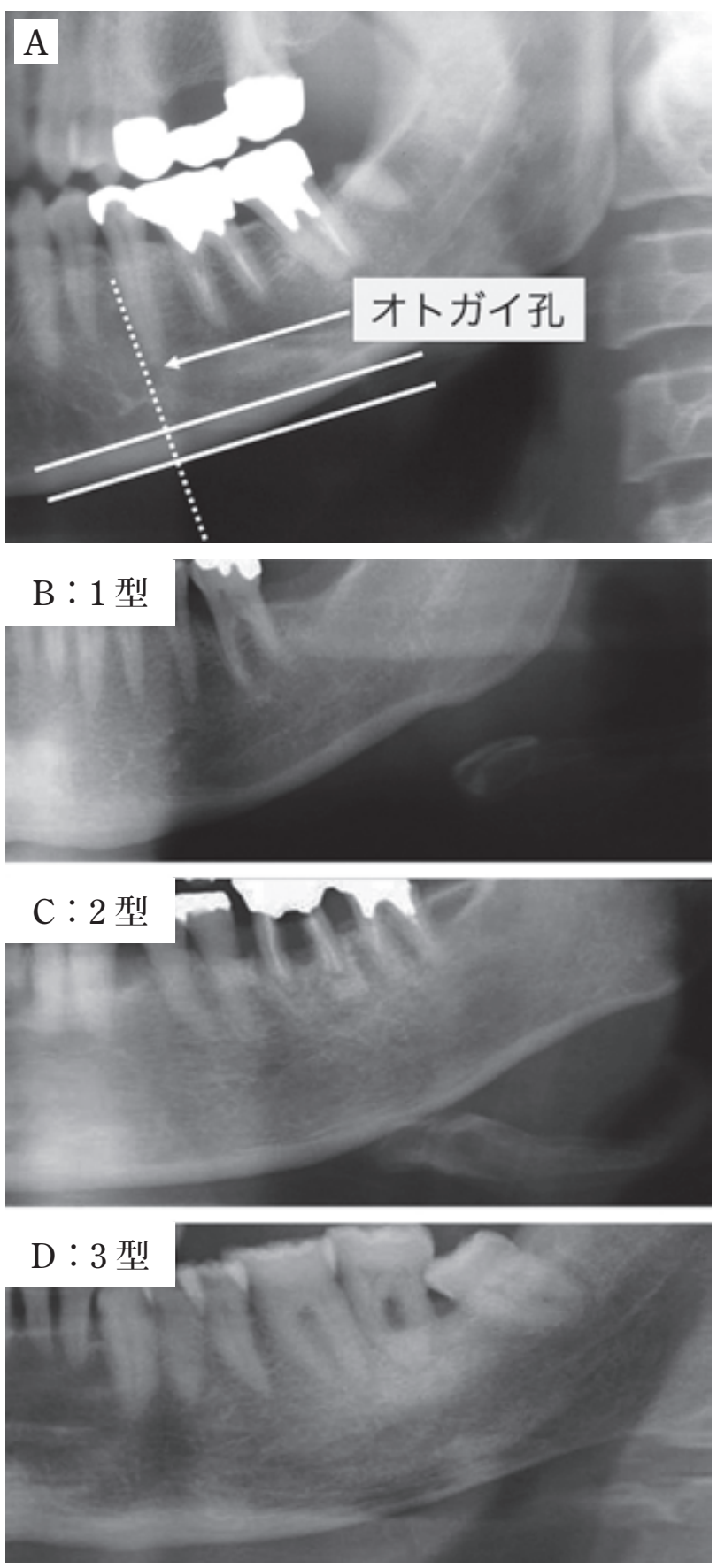

図 1 パノラマX 線写真を用いた骨粗鬆症スクリーニング A：下顎骨下縁皮質骨の厚みの測定部位. $B \sim C$ ：下顎骨下縁皮質骨の形態による分類の 1 例. (松本柬科大学 田口 明教授のご厚意により 文献 ${ }^{8,10}$ ) から写真を引用し, 一部改変)

に示すようにオトガイ孔下部で測定し , $2.8 \mathrm{~mm}$ 以下で骨粗 鬆症の可能性が高いと言われている ${ }^{7}$ )。皮質骨の「形態」 に関しては，図 1B〜D に示すように 1 型（正常）：両側皮 質骨の内側表面がスムーズ, 2 型 (軽度〜中程度粗鬆)：皮 質骨の内側表面は不規則となり内側近傍の皮質骨内部に線 状の吸収, 3 型（高度粗鬆化）：皮質骨全体に渡り高度な線
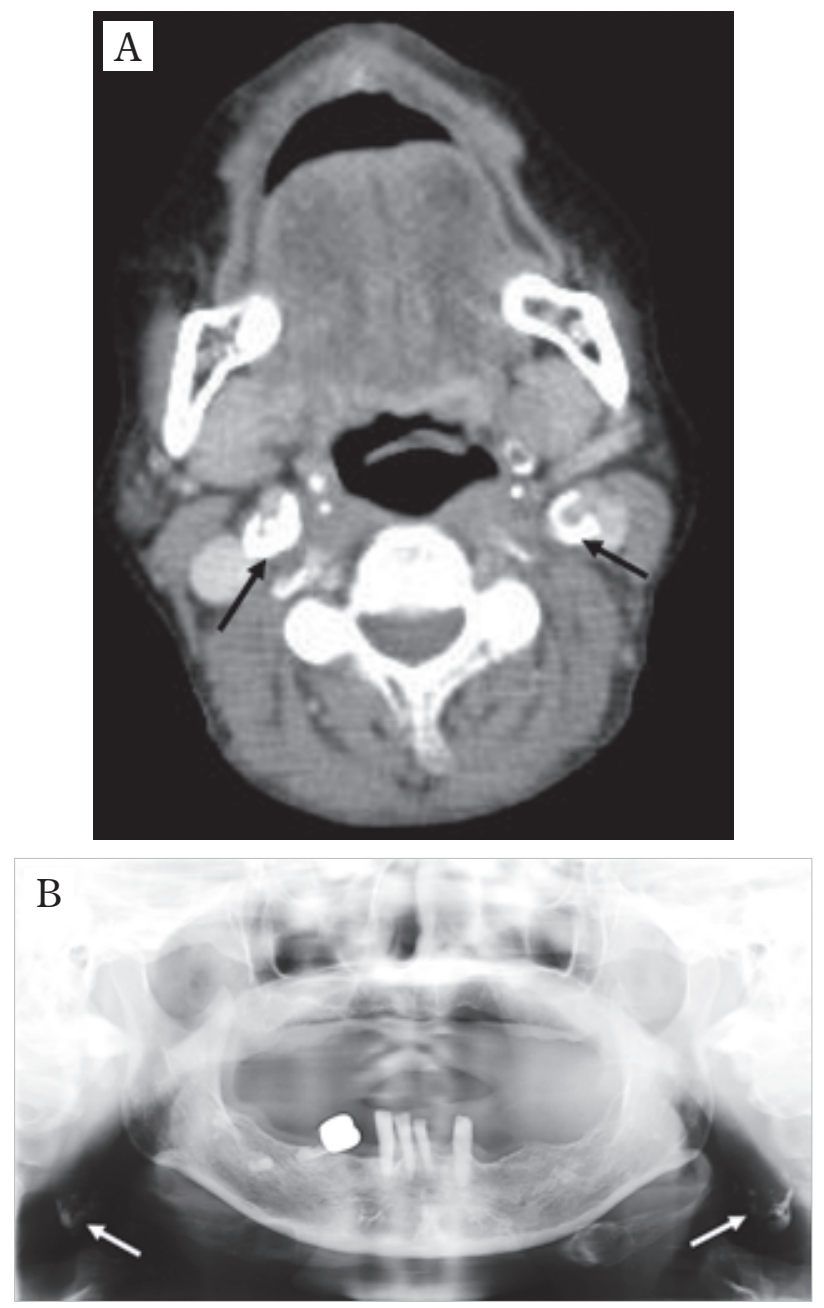

図 2 頸動脈の石灰化の 1 例

$\mathrm{A}$ ：CT 画像 $\mathrm{B}$ : パノラマ $\mathrm{X}$ 線写真

58 歳, 女性. 乳癌の手術目的に入院し, 手術前の口腔 精查と周術期口腔管理を勧められ受診。重度柬周病のた め, 残存柬はわずか 5 本であった.

パノラマX 線写真打よび CTにて, 両側頸動脈に石灰 化がみられた (矢印)。なお, 循環器内科の検査にて, 大 動脈弁および僧帽弁にも石灰化がみられた。

状の吸収と皮質骨の断裂，の 3 型の分類に基づいた骨粗鬆 症スクリーニングの有用性が報告されている ${ }^{8,9,10)}$.

骨粗鬆症と動脈硬化には密接な関係があることが報告さ れている ${ }^{11)}$. 動脈硬化による頸動脈の石疢化は, パノラマ $\mathrm{X}$ 線写真上で頸椎前方部に不透過像として確認される場合 があり ${ }^{12)}$, 骨粗鬆症と診断された患者に多くみられる ${ }^{13)}$. この石灰化は, 血管狭窄や脳虚血の危険を予測するサイン として有用であると報告されている ${ }^{14)}$ 。また, 藏周病が動 脈硬化のリスクファクターを上昇させることは以前より知 られており ${ }^{15)}$, Kamak ら 16) は, 柬周病が重症化するほど パノラマ X 線写真で頸動脈の石灰化がみられると報告して いる（図 2 に乳癌の術前 CT およびパノラマX 線検査にて, 

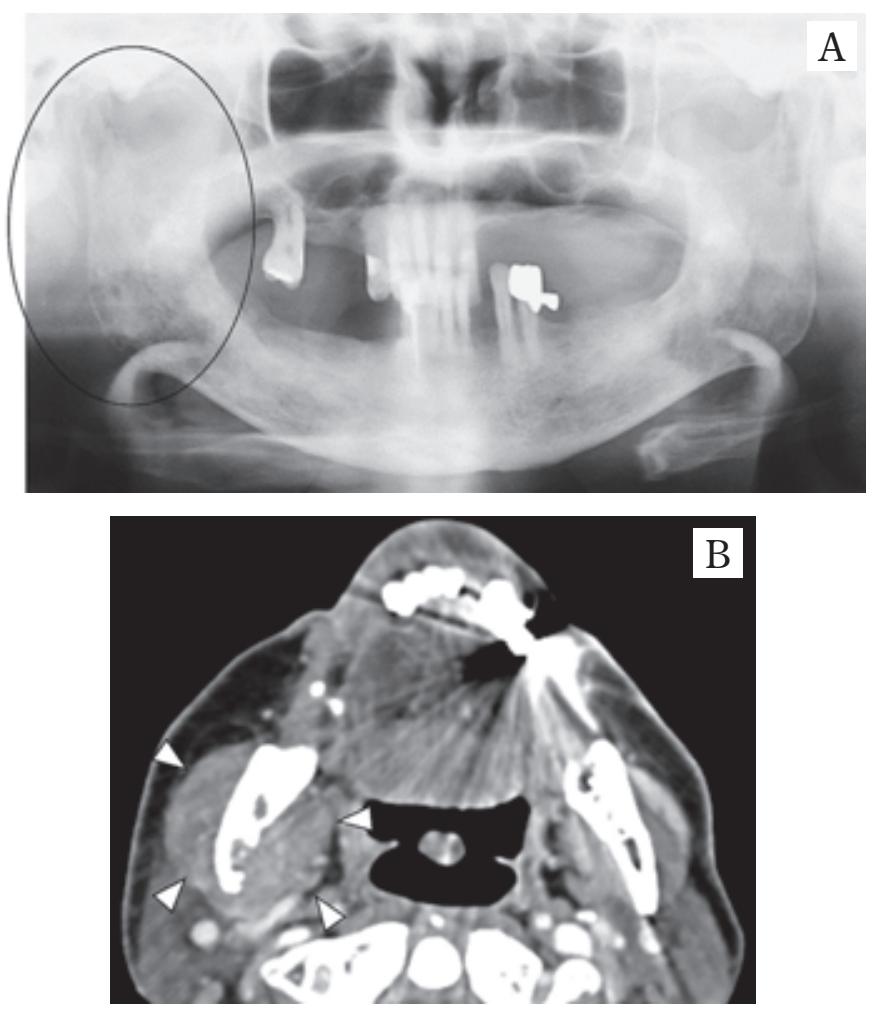

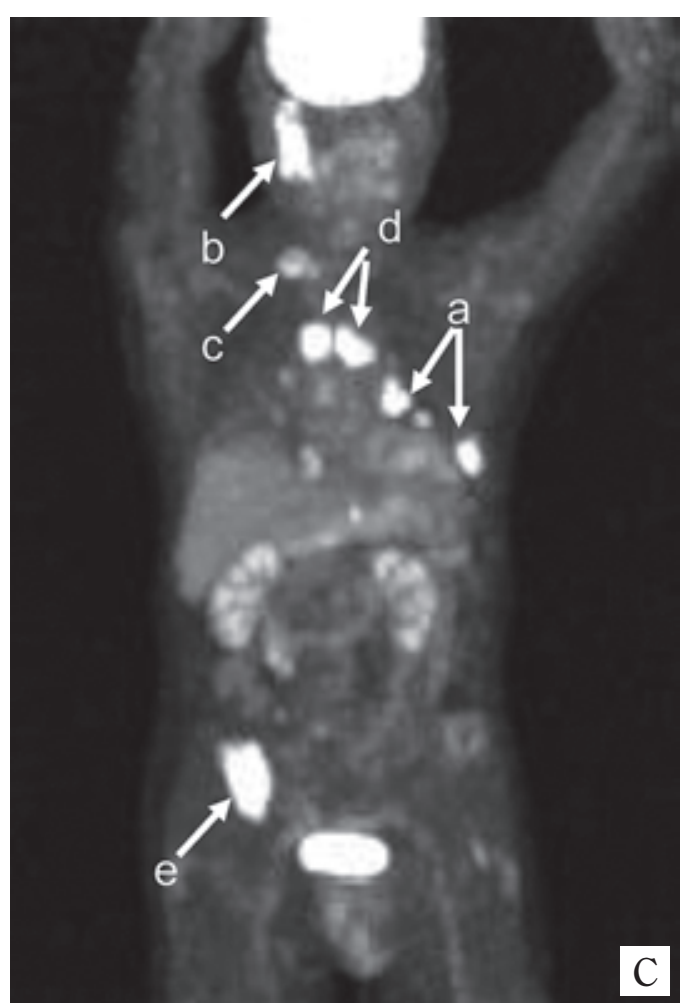

$\mathrm{C}$

図 3 転移性顎口腔がんの 1 例
$\mathrm{A}$ ：パノラマ $\mathrm{X}$ 線写真
$\mathrm{B}$ ：造影 CT 画像
C : FDG-PET 画像

84 歳, 男性. 下顎右側の疼痛と右耳前部の腫脹がみられ受診. 肺がん（小細胞がん, Stage 4) の診断のもと, 抗がん剂治 療を受けていた。

$\mathrm{A}$ ：パノラマX $\mathrm{X}$ 線写真では, 右側関節突起から下顎切痕および下顎角部にかけて皮質骨が粗造であった (丸で囲った部分).

$\mathrm{B}$ ：造影 CT では，右側下顎上行枝を取り囲む腫瘤性病変がみられ (矢頭)，下顎管は拡大し神経周囲浸潤が疑われた。

C：FDG-PET では, 肺がんおよび肺転移巣 (a) 以外にも, 右側下顎骨周囲 (b) , 椎体 (c), 縦隔リンパ節 (d), 腸骨 (e)に異常 集積がみられた。

頸動脈に石灰化がみられた重度歯周病を有する 1 例をしめ す)，頸動脈の石灰化のみられた患者に対しては, 歯周病 管理を行いながら, 動脈硬化を原因とするさまざまな疾患 について注意を払う必要がある。

\section{2.が ん}

悪性腫瘍のうち顎口腔領域へ転移（転移性顎口腔がん）を 認めるものは $1 \sim 3.4 \%$ 17 19) , 䫟口腔領域の悪性腫瘍のう ち他臓器からの転移が占める割合は 1 3.4\%であり 20 22), 転移性顎口腔がん自体は比較的まれである。そのなかで顎 骨への転移がみられる割合は $61.5 〜 82 \%$ と報告されてい る ${ }^{17,18,23)}$ 。一般に転移性顎口腔がんを有する患者は, すで に他藏器にも転移をきたしている場合が多く ${ }^{22)}$ ，とくに顎 骨への転移患者の予後は不良といわれている ${ }^{23,24)}$ (図 3 に 全身に転移のみられた，肺がん由来の転移性顎口腔がんの 1 例を示す)。そのため, 顎口腔領域の画像検査で転移性顎 口腔がんが疑われた場合には，早期の全身検索を進める必
要がる.

がん患者を診察する上で重要なことは, 今後のがん治療 に対して問題となる歯科疾患の有無とその治療法につい て，がん治療の開始時期と治療内容を踏まえて画像検索す ることである。とくに，抗がん剤治療（化学療法）を行う 患者は，抗がん剂により易感染性となり，健常時に何ら問 題とならなかった柬性病巣が感染症を引き起こす可能性が ある ${ }^{25)}$ ，柬性感染症の発現や程度は抗がん剂の強さや患 者の全身状態によって左右されるが, 軽度の歯性感染症で あっても抗がん剂の投与スケジュールが変更されることが ある、そのため, 抗がん剂治療を行う患者に対しては, 今 後の感染リスクを考慮し, たとえ症状のない㐘であっても 抜柬を選択する場合がある。

一方，頭頸部がんに対して放射線治療を行う患者では， 放射線性顎骨壊死のリスクを考慮する必要がある。放射線 性顎骨壊死は，下顎骨に60Gy 以上照射された場合に多く 発症し 26,27$)$, 抜㐘後に発症する場合が最も多く, 辺縁性柬 周炎, 根尖性柬周炎, 義柬性潰瘍なども原因となる ${ }^{28)}$. 抜 

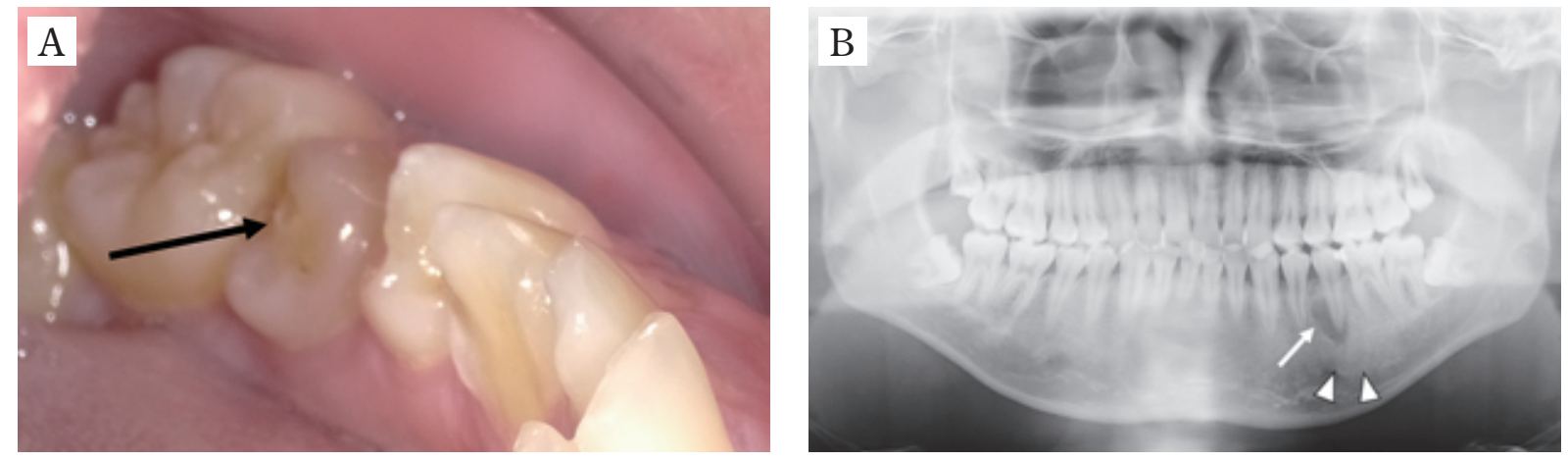

図 4 心臟血管病患者の 1 例

$\mathrm{A}$ ：口腔マクロ写真 $\mathrm{B}$ ：パノラマX $\mathrm{X}$ 線写真

20 歳, 男性. 心室中隔欠損の手術前の口腔精查および周術期口腔管理を依頼され, 手術の前日に受診。入院前に 近医歯科を受診したところ, 口腔に問題となる蒾はみられないと言われていた.

$\mathrm{A}$ ：全顎的に明らかなう蝕はみられないが, 左下 5 に中心結節の破折がみられた (黒矢印).

B : パノラマX $\mathrm{X}$ 線写真では左下 5 根尖に根尖病巣 (白矢印) と周囲に硬化性变化 (矢頭) がみられた。左下 5 根尖性 㐘周炎の診断のもと, 術前の抜菌が必要と判断し, 手術は延期された.

㐘に関しては, 口腔癌治療学会が出している「化学的根拠 に基づくロ腔癌診療ガイドライン 2013 年版」29) に掲載さ れている，「放射線照射内の抜歯は避けるべきか」の Clinical Question にたいして，「放射線性骨壊死（以下，骨壊死） は抜㐘を契機に発症することから原則的に禁忌である」と 答えている。しかしながら，「放射線治療後に抜㐘が避け られないこともある。原則的には禁忌であるが, 放射線治 療の内容, 抜柬部位, 抜柬の適応, 抜柬術式, 補助療法を考 慮することにより，放射線治療後の抜柬が必ずしも禁忌で はない」とも付け加えられている ${ }^{30)}$. したがって, 今後抜 歯となる可能性が高いと判断された歯に対しては, 放射線 治療前の抜柬が推奨される。さらに, 創傷治癒の観点から， 普通抜㐘では少なくても 1 週間以上, 難抜柬は少なくとも 2 週間以上間隔をあけて, 放射線治療を開始する必要があ る ${ }^{31)}$. よって, 顎顔面領域の放射線治療を行う患者の抜㐘 では, 放射線の照射量, 範囲および時期を十分に考慮する 必要がある。

\section{3．心臓血管病}

㐘周病を中心とした口腔の慢性感染症と全身疾患との関 係，いわゆる「Periodontal Medicine」が注目されている ${ }^{32,}$ 33) 。とくに口腔細菌は感染性心内膜炎の原因菌として知ら れており ${ }^{34,35)}$, 柬性病巣感染は感染性心内膜炎の最多誘因 であり ${ }^{36,37)}$ ，感染性心内膜炎が柬科処置による菌血症に よって惹起されるという報告もある ${ }^{38)}$ 。菌血症を起こす 柬科処置としては, 抜苗が最もよく知られており, その他 の出血を伴う口腔外科処置, 茵石の除去 (スケーリング), 感染根管治療なども原因としてあげられる ${ }^{39)}$ 。人工并置
換術などの心臓の手術を行う患者に対しては,「致死的疾 患の原因となりうる歯は, 安全に処置ができる間に対処す る」という考え方が必要で, 術前の積極的な感染巣の除去 と術後の口腔管理が求められる ${ }^{33)}$ (図 4 に術前のパノラマ $\mathrm{X}$ 線検査で歯性病巣感染が発見され，心臓の手術が延期と なった 1 例を示す)。すなわち, 菊性感染巣の有無と治療 の必要性を正しく判断することが重要である.

\section{4. 遺伝性疾患および内分泌疾患}

歯科疾患の多くは後天的要因が大きいが, 口腔症状が全 身疾患の部分症状としてあらわれている場合には遺伝が関 わっていることも少なくない. 顎骨の多発性骨腫を特徴と する Gardner's syndrome は癌化傾向の強い大腸ポリープ がみられ，顎骨の硬化性変化や歯の萌出遅延を特徴とする 大理石骨病は全身骨の易骨折性変化とさまざまな脳神経障 害が生じる ${ }^{40)}$ (図 5 に大腸ポリープの手術前のパノラマ X 線写真で多発性の骨腫のみられた Gardner's syndromeの 1 例を示す)。このように, 口腔症状に遺伝が関わっている 場合には重篤な全身疾患を伴うことがあるため, 我々は遺 伝性疾患の特徴的画像所見を理解しておくことに加え, 全 身疾患に関する家族歴の聴取を忘れないことが重要であ る.

内分泌臟器に腫瘍が発生すると, ホルモンの過剩分泌が 生じることがある。例えば副甲状腺の腫瘍は副甲状腺ホル モン (パラソルモン) を過剩に分泌し, 全身の骨密度の低 下と柬槽硬線の消失をきたす。また，下垂体に腺腫が発生 すると, 時に成長ホルモンの過剩分泌が起こり, 顎骨の発 育異常による咬合不全となる場合がある ${ }^{41}$ ) (図 6 に咬合不 

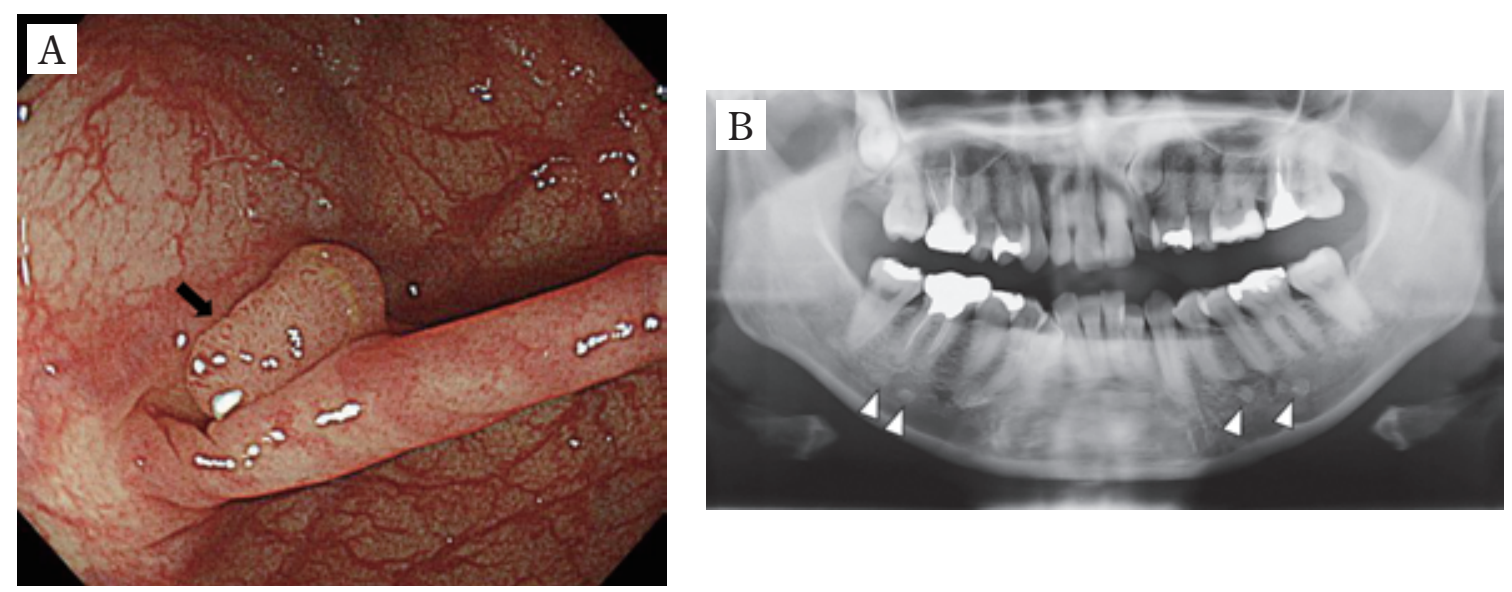

図 5 Gardner's syndrome $の 1$ 例

$\mathrm{A}$ : 下部消化器内視鏡検查写真 B : パノラマ X 線写真

42 歳, 女性. 大腸ポリープ (矢印) の手術前の口腔精査拉よび周術期口腔管理を依頼され受診。術前のパノラマ $\mathrm{X}$ 線写真にて多数の骨腫が確認された (矢頭)。問診にて母親も 30 歳代で多発大腸ポリープのため大腸摘出術を受 けていたことが分かった。顎骨の多発性骨腫と家族性の大腸ポリープがみられたことから, Gardner's syndrome と 診断された.
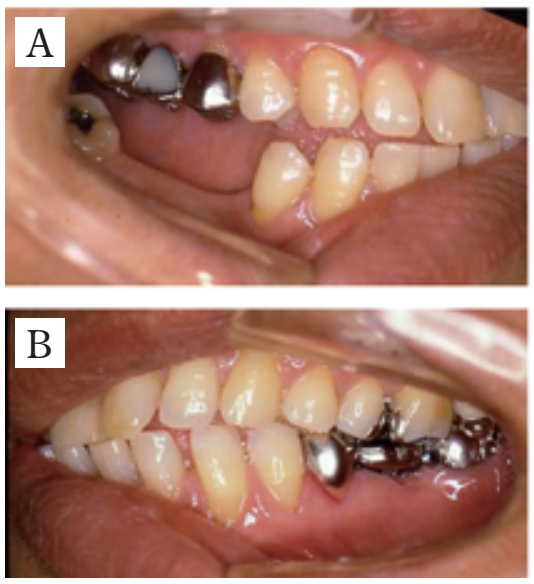

図 6 下垂体腺腫の 1 例
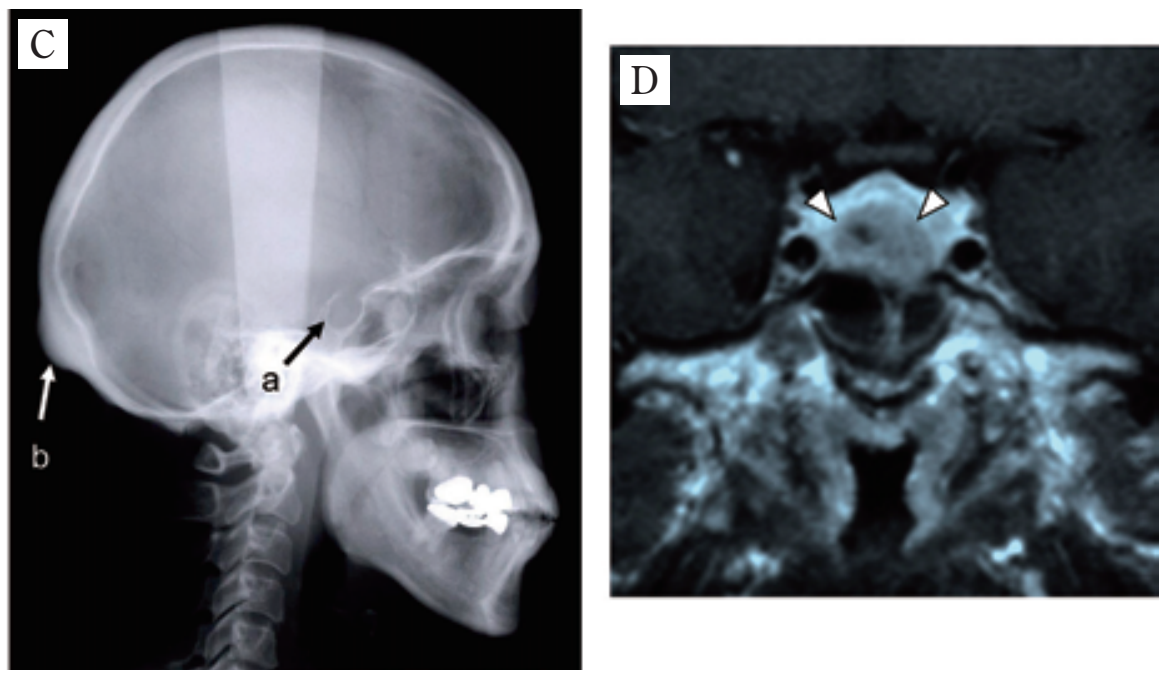
A, B：口腔マクロ写真
$\mathrm{C}$ ：側面頭部 X 線規格写真
$\mathrm{D}$ : 造影 $\mathrm{T} 1$ 強調 MR 画像

45 歳, 女性. 右側下顎臼柬部の咬合不全を訴え受診。前柬部は切端咬合であり, 右下 234,8 と右上 234,7 の開口 がみられたが, 左側臼㐘部には明らかな咬合異常はみられなかった。側面頭部エックス線写真では, トルコ鞍の開大 (a) と後頭隆起の突出 (b) がみられた。 MR画像にて, トルコ鞍から鞍上部に突出する腫瘤性病変 (矢頭) を認め, 血 液検査にて成長ホルモンが高值であったことから, 成長ホルモン産性下垂体腺腫（末端肥大症）と診断された (文献 ${ }^{34)}$ より引用し, 一部改変)。

全のみられた下垂体腺腫の 1 例を示す)。これらの異常に 対しては，単なる局所の異常なのか，それとも全身疾患の 部分症状なのかを見極める必要がある.

\section{5．薬剤関連性疾患}

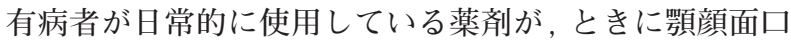
腔領域に重篤な合併症を引き起こすことがある。代表的な
例として，ビスフォスフォネート製剤などの骨吸収抑制薬 や血管新生阻害薬を使用している患者にみられる顎骨壊死 （MRONJ）があげられる。これらの薬剤を使用する患者に は, 使用前に顎骨内の病変の有無を慎重に診査する必要が ある。

メトトレキサート（MTX）は慢性関節リウマチの有効な 治療薬として頻用されている。しかし, 時にリンパ増殖 性疾患（MTX関連リンパ増殖性疾患）を発症し, 皮下腫 

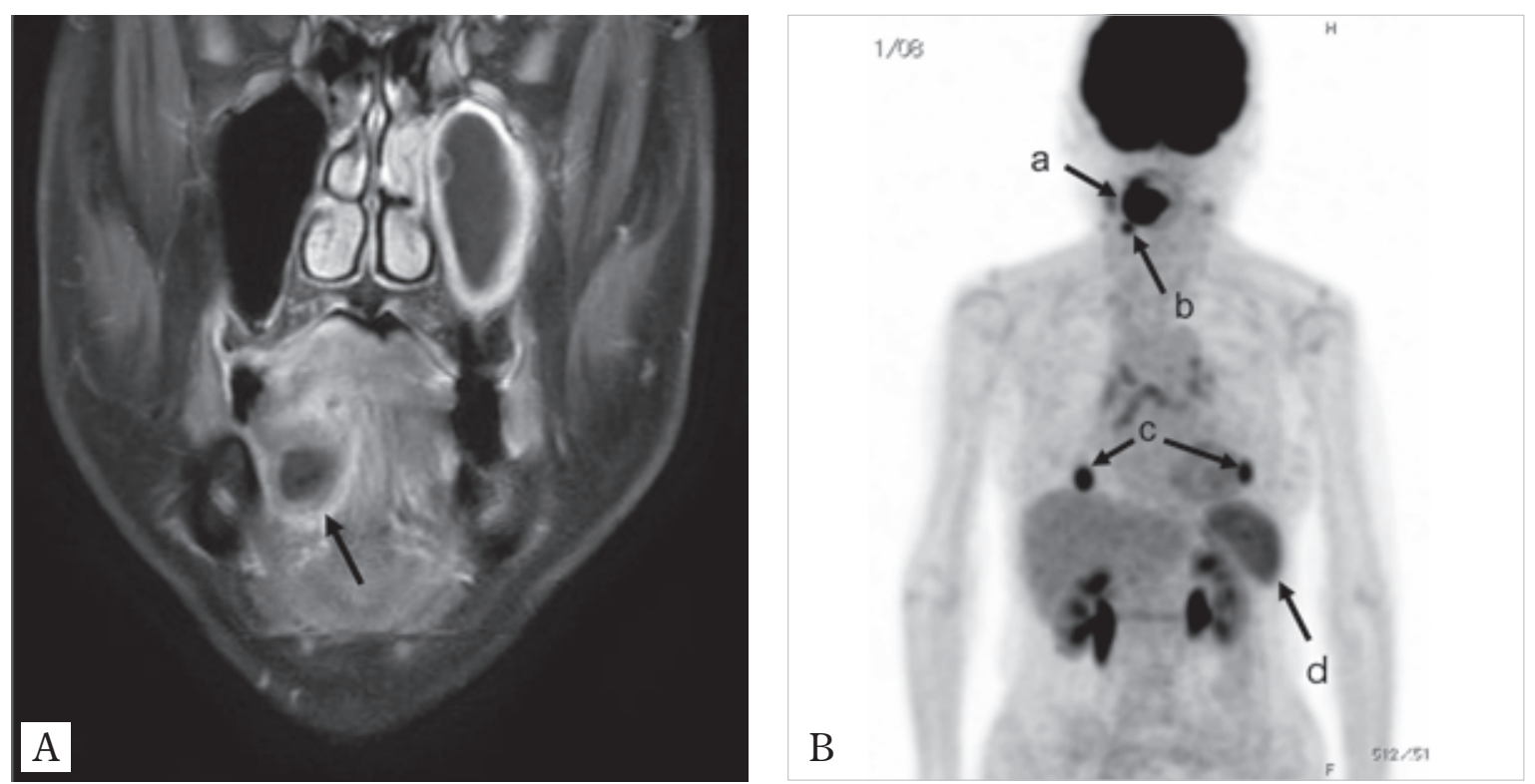

図 7 MTX 関連リンパ増殖性疾患の 1 例

$\mathrm{A}$ ：造影 $\mathrm{T} 1$ 強調 MR 画像 B：パノラマX 線写真

67 歳, 女性. 右側の舌下面から口底にかけて潰瘍を伴う無痛性の腫瘤ができたため受診. 5 年ほど前から, 慢性関 節リウマチにて MTX 療法を受けている.

A：MR 画像にて口底右側に辺縁優位に造影される腫瘤性病変を認めた (矢印).

B：FDG-PET では，口底右側（a），頸部右側レベル II / IIIの境界付近のリンパ節（b)，両肺下葉（c）扎よびびまん性 に脾臟 (d) に高集積がみられた。

瘤, 難治性咽頭痛, 扁桃腫大, 異常肺陰影などがみられ ${ }^{42)}$, 口腔領域には潰瘍形成や骨露出がみられることがある ${ }^{43)}$ (図 7 に口底部に潰瘍を伴う腫瘤がみられた MTX 関連リ ンパ増殖性疾患の 1 例を示す)。よって, MTX 使用患者の 口腔領域に上記症状がみられた場合には, FDG-PET (18FFluorodeoxyglucose positron emission tomography）などに よる全身の画像検索を行い ${ }^{44)}$, 医科診療科と連携して休薬 による経過をみる必要がある。

\section{ま と め}

超高齢社会に突入した我が国では，国民の健康長寿に向 けた医療全体の在り方が大きく変化している。とくに，周 術期口腔管理をはじめとした, 高齢者や有病者に対する医 科歯科連携の充実は，国策として推進されている。そこで 本稿では，さまざまな医科的疾患 (全身疾患) を有する患 者 (有病者) の口腔領域の診察をする上での注意点につい て画像を交えて概説した。

\section{謝辞}

画像提供をいただきました松本歯科大学歯科放射線学講座 田口 明教授, 東北大学大学院蒾学研究科口腔診断学分野 小嶋 郁穂助教, ならびに東北大学大学院柬学研究科顎顔面・口腔外 科学分野の先生方に感謝いたします。最後に, 細部にわたりご
助言いただきました東北大学大学院㐘学研究科口腔診断学分野 西岡貴志助教ならびに阪本真弥講師に感謝いたします.

\section{引用文 献}

1) Akutsu Y, Matsubara H, et al : Impact of preoperative dental plaque culture for predicting postoperative pneumonia in esophageal cancer patients. Dig Surg 25: 93-97, 2008.

2 ) Yoneyama T, Yoshida M, et al : Oral care and pneumonia. oral care working group. Lancent 354: 515, 1999.

3 ) Tsuboi M, Hasegawa Y, et al : Mortality and mobility after hip fracture in japan; a ten-year follow-up. J Bone Joint Surg Br 89: 461-466, 2007.

4 ) 田口 明：加齢に伴う変化. 岡野友宏, 小林 馨, 他 編著：歯科放射線学. 第 6 版, 医歯薬出版株式会 社, 東京, 2018, 419-424 頁.

5 ) Taguchi A : Triage screening for osteoporosis in dental clinics using panoramic radiographs. Oral Diseases 16: 316-327, 2010.

6 ) Katsumata A and Fujita H : Progress of computer aided detection / diagnosis (CAD) in dentistry. Japanese Dental Science Review 50: 63-68, 2014.

7 ) Taguchi A, Ohtsuka M, et al : Risk of vertebral osteoporosis in post-menopausal women with alterations of the mandible. Dentomaxillofac Radiol 36: 143-148, 2007.

8 ) Taguchi A, Sugino N, et al : Detecting young Japanese adults with undetected low skeletal bone density 
using panoramic radiographs. Dentomaxillofac Radiol 40: 154-159, 2011.

9 ) Yamada S, Uchida K, et al : Panoramic radiography measurements, osteoporosis diagnoses and fractures in Japanese men and women. Oral Dis 21: 335-341, 2015.

10) Yamada S, Uchida K, et al : Panoramic radiography measurements, osteoporosis diagnoses and fractures in Japanese men and women. Oral Dis 21: 335-341, 2015.

11) Tamaki J, Iki M, et al : Low bone mass is associated with carotid atherosclerosis in postmenopausal women: the Japanese population-based osteoporosis (JPOS) cohort study. Osteoporos Int 20: 53-60, 2009.

12）大田原宏美, 神部芳則, 他：パノラマX線画像による 頸動脈の石灰化の評価. 日口腔内誌 21: 33-37, 2015.

13) Iwamoto $Y$, Uchida $K$, et al : Osteoporosis, osteoporotic fractures, and carotid artery calcification detected on panoramic radiographs in Japanese men and women. Oral Surg Oral Med Oral Pathol Oral Radiol 121: 673-680, 2016.

14) Nandalur KR, Baskurt E, et al : Carotid artery calcification on CT may independently predict stroke risk. Am J Roentgenol 186: 547-552, 2006.

15）山崎和久, 高橋直紀, 他: 第 1 部臨床研究からの工 ビデンス 1) 㐘周病と血管障害. 特定非営利活動 法人日本蒾周病学会編：蒾周病と全身の健康。第 1 版, 医柬薬出版, 東京, 2016, 10-27 頁.

16) Kamak G, Yildirim E, et al : Evaluation of the relationship between periodontal risk and carotid artery calcification on panoramic radiographs. European journal of dentistry 19: 483-489, 2015.

17) Bhaskar SN : Oral manifestation of metastatic tumors. Postgrad Med 49: 155-158, 1971.

18) Stypulkowska J, Bartkowski S, et al : Metastatic tumors to the jaws and oral cavity. J Oral Surg 37: 805808, 1979.

19）土井勝之, 浅野貴徳, 他：下顎骨転移 7 症例の臨床 検討. 頭頸部外科 19: 161-165, 2009.

20) Cash CD, Royer RQ, et al : Metastatic tumors of the the jaws. Oral Surg Oral Med Oral Pthol 14: 897-905, 1961.

21) Meyer I and Shklar G : Malignant tumor metastatic to mouth and jaws. Oral Surg Oral Med Oral Pthol 20: 350-362, 1965.

22) van der Waal TI, Buter J, et al : Oral metastases: report of 24 cases. Br J Oral Maxillofac Surg 41: 3-6, 2003.

23) Hirshberg A, Shnaiderman-Shapiro A, et al : Metastatic tumors to the oral cavity-Patho-genesis and analysis of 673 cases. Oral Oncol 44: 743-752, 2008.

24）片岡 聡, 柴田昌美, 他：口腔転移性悪性腫痬 17 例 の臨床的検討。日口外誌 49: 566-569, 2003.

25) Toljanic JA, Bedard JF, et al : A pilot study to evaluate a new dental assessment and treatment paradigm for patients scheduled to undergo intensive chemotherapy for cancer. Cancer 85: 1842-1848, 1999.

26) Thorn JJ and Hansen HS : Osteoradionecrosis of the jaws: clinical characteristics and relation to the field of irradiation. J Oral Maxillofac Surg 58: 1088-1093, 2000.

27) Reuther T, Schuster T, et al : Osteoradionecrosis of the jaws as a side effect of radiotherapy of head and neck tumour patients - a report of a thirty year retrospective review. Int J Oral Maxillofac Surg 32: 289295, 2003.

28）松本和秀, 榎本明史, 他：頭頸部癌患者における放 射線性顎骨壊死に関する臨床的検討。近畿大医誌 41: 77-84, 2016.

29）日本口腔腫瘍学会, 日本口腔外科学会 編: 科学的根 拠に基づく口腔癌診療ガイドライン。2013版, 金原 出版, 東京, 2013, 142-143 頁.

30) Nabil S and Samman N : Incidence and prevention of osteoradionecrosis after dental extraction in irradiated patients: a systematic review. Int J Oral Maxillofac Surg 40: 229-243, 2011.

31）梅川仁悟：放射線性下顎骨骨壊死の予防と治療. 頭 頸部癌 30: 434-438, 2004.

32）新田 浩, 石川 烈：㐘周病と全身疾患の関連につ いて. The Quintessence 18: 87-96, 1999.

33）湯村直子, 大曽根 洋, 他：人工弁置換術の術前処 置として困科的管理を要した僧帽弁閉鎖不全症患者 の一例. 日有病歯誌 12: 159-164, 2003.

34) Bayliss R, Clarke C, et al : The microbiology and pathogenesis of infective endocarditis. Br Heart F 50: 513-519, 1983.

35）奥田克爾, 加藤哲男, 他: 柬周病原生バイオフィルム は動脈硬化に関わるか. 㐘科学報 103: 775-783, 2003.

36) 高山守正: 感染性心内膜炎 予防, 病態, 内科治療. 内科 87: 103-109, 2001.

37）松下雅英, 鶴谷善夫, 他: 感染性心内膜炎の臨床像 と治療成績。心藏 34: 646-654, 2002.

38) Okell CC and Elliott SD : Bacteremia and oral sepsis with special reference to the aetiology of subacute endocarditis. Lancet 2: 869-872, 1935.

39) Heimdahl A, Hall G, et al : Detection and quantitation by lysis-filtration of bacteremia after different oral surgical procedures. J Clin Microbiol 28: 2205-2209, 1990.

40）矢野淳也, 新谷 悟, 他：大理石骨病に併発した顎 骨骨髄炎の 4 例。日口外誌 49: 363-366, 2003.

41）飯久保正弘, 阪本真弥, 他: 全身疾患と口腔症状に 関する診断学的研究 一第 3 報 口腔症状により発見 された下垂体腺腫の 2 例一. 東北大柬誌 19: 51-63, 2000.

42）日本リウマチ学会. MTX 診療ガイドライン策定小 委員会 編：関節リウマチ治療に打けるメトトレキ サート（MTX）診療ガイドライン 2016 年改訂版. 2016, p66-95.

43）齋藤圭輔, 小澤智宣, 他：上顎柬肉に発症したメト トレキサート関連リンパ増殖性疾患の 1 例一口腔領 域発症例診断に打ける文献的考察一。㐘科放射線 58: 19-23, 2018.

44) Watanabe $\mathrm{S}$, Manabe $\mathrm{O}$, et al : The usefulness of 18F-FDG PET/CT for assessing methotrexate-associated lymphoproliferative disorder (MTX-LPD). BMC Cancer 635: 3-8, 2016. 